\title{
A comprehensive test-ban now, please
}

The case for a comprehensive test-ban treaty, necessary for global security and civility, is made more pointed by worries about proliferation. But now the British seem to be dragging their feet.

WHAT should be the next step in the process of strategic arms control that has powerfully, if occasionally, lifted spirits in the past two decades? The important article by Lord Zuckerman on page 392 shows what has been achieved, often against the prevailing odds, to reduce the risks of global nuclear war. The partial test-ban treaty of 1963, in whose negotiation the British played a leading part - remember Prime Minister Harold Macmillan's return from Moscow in a white fur hat? - and in which Zuckerman's personal role was central, would have been necessary on environmental grounds. Zuckerman now argues that it is time to complete those distant negotiations to arrive at a comprehensive testban treaty (CTB).

None of this belittles the importance of what has been achieved since 1963. A string of treaties now restricts the capacity of great powers to wage nuclear war. The most remarkable is the Anti-Ballistic Missile Treaty, predicated on the counter-intuitive view that the world would be safer if the nuclear powers were not defended against attacks by strategic missiles. At least on paper, there is now also a prospect of substantial reductions in the numbers of strategic missiles deployed (see Nature 361, 1; 1993). Yet all that, in changed circumstances, does not suffice for stability. A CTB is the logical next step.

For more than three decades, since technical talks on the feasibility of a CTB began on the coat-tails of the second United Nations Conference on the Peaceful Uses of Atomic Energy in 1958, the CTB has been waiting in the wings. The first serious negotiation, marked by an Anglo-American and Soviet moratorium on testing lasting more than two years, was ostensibly defeated by uncertainties about the remote detection of underground explosions by seismic means; the determination of the military to improve the efficiency of their warheads was still more influential. Then, towards the end of Jimmy Carter's US presidency, there were high hopes that a CTB would materialize. But that treaty, which would have been signed by Britain, the Soviet Union and the United States, would not have met the present need, while Carter's successor, President Ronald Reagan, would not have fought for its ratification in the US Senate.

Circumstances are now different. Zuckerman remarks on the consequences of the fragmentation of the Soviet Union into several independent republics: those with nuclear weapons on their soil are potentially nuclear powers. (The Ukraine, by some accounts, is negotiating with the West to trade this potential for more urgent needs, cash among them.) Since
1958, France and China have emerged as nuclear powers while, more recently, countries as different (or, rather, as similar) as India, Pakistan, Iraq and North Korea have acquired the reputation of nursing nuclear ambitions. To make sense now, a CTB must be genuinely comprehensive.

That objective has been made more urgent by the impending review conference of the Non-Proliferation Treaty (NPT) in 1995, when the parties to the treaty will have to decide whether it continues. Previous review conferences have been rowdy occasions, partly because the nuclear powers have not been able to report much progress in strategic arms control. Two years from now, there will be more to boast about, but the nuclear powers themselves will be alarmed at the difficulties of policing the NPT. The safeguards regime operated by the International Atomic Energy Agency is more effective than its extreme critics say, but it is cumbersome. If signatories of the NPT were also signatories of the CTB, policing would be a lot simpler. So the established nuclear powers now have an interest in a CTB that transcends the eagerness of their military to keep on testing weapons.

Except, it seems, in Britain. Zuckerman, as loyal a public servant as the British government could find, is plainly dismayed that the British have declined to follow France, Russia and the United States in the current moratorium on nuclear testing. They are, of course, in an odd position, having nurtured plans to deploy Trident missiles in submarines and an air-launched nuclear weapon still in the early stages of development. They say they need to test the warheads for these weapons, but President Bill Clinton says the Nevada test-site to which the British have access will be shut in 1996. Will it not be ironical if the government that rightly boasts of having been the driving force behind the Partial Test-Ban Treaty is seen to drag its feet on the CTB for the sake of strategic plans irrelevant to its present military needs? The British government should read Zuckerman and then change tack.

\section{Europe's research}

A meeting of research council heads will put pressure on Brussels and may give Strasbourg a bigger role.

THE arrival in Brussels of Antonio Ruberti as the new member of the European Commission responsible for research has been widely welcomed. He is adroit, energetic 